\title{
The Effects of Simulations and Animations on Students' Motivation in a Computer Course
}

\author{
Oğuzhan ÖZDEMIR * and İbrahim Enes ÖNER \\ Firat University, Education Faculty, Elazı̆ğ, Turkey
}

\begin{abstract}
The purpose of this study is to investigate the effects of simulations and animations on students' motivation in a computer course about hardware. The "Instructional Materials Motivation Survey [IMMS]" - "Öğretim Materyalleri Motivasyon Anketi "[ÖMMA] developed by JM Keller was administered at both the beginning and end of the course in order to examine, animation and simulation aided the effects of the activities carried out on the students' motivation. The survey consists of 24 items in a structure which includes four factors (attention, relevance, confidence, satisfaction). The reliability of the questionnaire was found as 0.83 for (Cronbach's Alpha) internal consistency coefficient total polls and 0.79 and 0.69 for sub-factors, respectively. Experimental design was used in the study. The survey was administered to 30 students studying at Amasya University, in the Faculty of Education, Classroom Teaching Department; 32 students from the Mathematics Teaching Department; and 26 students studying Theological Science. The results were analyzed using SPSS 18. According to the research findings, it was observed that using simulations and animations in the computer course about hardware of the Classroom Teaching Section, Theological Mathematics Section and Theological Science had a positive effect on the motivation of students and had a significant differentiation according to the situation that simulations and animations have not been applied (sig <0.05).
\end{abstract}

Keywords: Motivation, Animation, Simulation, IMMS

\section{Introduction}

As with any work, at the beginning of education, there is a specific planning and preparation process. These processes are both instructive processes that should be considered by both the learner and teacher. The planning process is based on theoretical knowledge. As well as psychological preparation of the preparatory process of the preparation of the individual materials is concerned. Here, the factors affecting learning motivation enter into operation. They consist of Motivation, commitment, and self-giving, and cover situations such as goal orientation with the senses and sensory process. Also (Reschly \& Christenson, 2006) have shown that motivation energy in the behavior of individuals have expressed the excitement. Motivation is an emotional concept about how they feel about their work and how they treat other individuals. (Keenan, 1996).

While the motivation mobilizing individual and environmental factors in psychology, TDK

\footnotetext{
* Computer Education and Instructional Technology, ienesoner@gmail.com
} 
dictionary 'in (TDK, 2015), "it is expressing internal factors that control the behavior for a purpose in living. Bring a motion to refer the motion. The driving force, internal power the router to act", and it describes managerial aspects of the reason for the behavior of the individual in the group and all of the energy factor expressing the results (Falcon, 2004).

Motivation is the process of the organization and motivation and incentives for individuals to take action in order to create a business environment that will meet the needs of individuals. The direction of the movement is made quickly on the severity of impact and sustainability. (Küçükahmet, 2001)

(Lussier, 1996) argues that motivation is an internal process that directs people to move to obtain needs. Keller (1983) has defined the direction and magnitude of the behavior as motivation, especially stated that the indicators of the motivation effort.

In the life education; motivation to participate in the activities offered by the school students, and school attendance, educational participation, and while expressing that two-sided interaction with the school (Natriello, 1984) give energy motivated individual, is effective in becoming willing to act, to increase the effectiveness of the teaching-learning process. There appears to be one of the issuing of the most important factors to the fore (Akbaba, 2006), and students with increased active learning through motivation and education to become active they are for classroom discipline problems in teaching has been shown to be reduced (Stern \& Huber, 2012) .Also, well-motivated students function as an important source of job satisfaction for teachers, positively contributing to class (Yuksel, 2004)

A student who is not motivated enough is literally not ready for education. Students are more curious about their topics of interest and when they are naturally motivated, they are motivated to learn in a short time in a natural way. But all subjects do not naturally arouse the same interest for all students (Elik, 2003). But by all of them, with the difficulties in school because of inability to be motivated to participate in the courses students to truancy leads to a break in education (Reeve, Jang Carrell, Jeon, \& Barchi , 2004).

Many scientists examined the relationship between the educational achievement motivation, have developed various theories and models according to different conclusions Keller, Wlodkows that Herzberg, Maslow, Mayo, McClelland, McGregor, Likert, Luthans and Vroom's about . Motivated theory, of the students' knowledge and skills to learn and internalize motivation revealed that there is a significant effect (Dede \& Yaman, 2008).

Last, but not from person to person level of motivation, a change from case to case and can keep the change because the desired level of motivation is difficult at different time intervals (Cooke, 2008).

Computer animation has emerged with the introduction of digital computers into everyday life in the 1960s and has been evolving ever since. The word "Animation" comes from the Latin "anima", which means revive (Foley, Dam, Feiner, \& Hughes, 1990).

Elliot and Miller (Elliot \& Miller, 1999) animation, allows us to think that it really is defined as movement.to create a moving image showing several stationary objects or moving objects in these images live and in quick succession

Discrimination by Linn et al. (Linn, Chang Chien Zhang, \& McElhaney, 2010), the computer displays the interactive visualization of scientific events or computer-based animations 
(models, such as virtual scientific experiments) were characterized by the depiction.

Neumann et al. (Neumann, Hood, \& Neumann, 2012) have made the qualitative analysis of the perception on the simulation software of the students and provide immediate feedback of simulations, practice taking is to help course with useful visuals and practices for learning and besides pursuits create relevant lessons more providing students with the motivation to actively participate in such simulations reported perceived as beneficial.

With simulations, videos, graphics, animations, audio and multimedia learning elements such as text, students have the potential to engage, which ensures their effective participation in the course. However, these items should be just as simple as pressing the button detection is in use to interact in a simple way (Hotchkiss, 1994).

By using computer in everyday life use, using them especially in science and technology with the introduction of technology has increased very fast. Researchers have developed various methods and techniques to help students to understand difficult issues in a more understandable manner for use in classrooms and labs. These models are prototypes, statements, oral statements, computer simulations, and so on. (Mickleborough \& Wareham, 1994).

In light of this information, the foundation of animation is animation. It means to portray an event or phenomenon with fair or unrealistic approach to transfer. It uses the imagination to reflect events that the animation. The event format is not necessarily reflecting fair value. For example, we want to return the hard disk, and information can be read in a way to revive the animation. There is no need to change the animation and change is not permitted. In a simulation, events cannot go beyond the limits set by science and mathematics. It should be completely factual results. Everything must fit and should not pose real certainty. People using the system can intervene in the simulation environment. For example, you can replace the hard disk's data reading speed and spin, and can observe and interpret the results.

\section{Method}

\section{Research Models}

Experimental research methods were used in our research. Research conducted to investigate the effect on the dependent variable is the environment created by experimental research investigators to determine the cause and effect relationship between variables. (Büyüköztürk, Sword Lighter, Akgun, Black, \& Demirel, 2012)

\section{Working Group}

The easy sampling method was used to determine the working groups, and existing classes in the school were randomly assigned to the control group. The Working group is designated as 30 students of Classroom Teaching, 32 students of Mathematics Teaching and 26 students of Theology in Amasya Education Faculty of Amasya University.

\section{Data Collection Tool}

In the study, the "Instructional Materials Motivation Survey [IMMS] - Teaching Materials Motivation Questionnaire [OMMA]", developed by JM Keller and translated into Turkish by (Kutu \& Sözbilir, 2011) was used to collect data. The internal reliability of the 
questionnaire (Cronbach's alpha) had an internal consistency coefficient of 0.83 for the total survey, and 0.79 and 0.69, respectively, for the sub-factors. (Kutu \& Sözbilir, 2011)

\section{Data Analysis}

SPSS 18 was used for the data analysis. The data obtained using the pre-test and posttest were analyzed by means of an independent t-test calculation.

\section{Results and Comments}

The data obtained from the data collection tool has been revised entering the statistics program. Incomplete and incorrect data corrected determined, the students' answer some of their missing items have been completed in accordance with the format of the material to change state average. Entering the arithmetic mean of the range of the missing ingredient in this kind of lack of data does not make much impact on the result of a change agent ((littler.aj \& The rubind.., 1987); (S., 2002)).

Table 1. Department of Mathematics Student Data

\begin{tabular}{|c|c|c|c|c|c|c|c|}
\hline Variaties & & $\mathrm{N}$ & $\bar{X}$ & Ss & $\mathrm{t}$ & sd & $\mathrm{p}$ \\
\hline Attention & $\begin{array}{l}\text { Pretest } \\
\text { Posttest }\end{array}$ & $\begin{array}{l}30 \\
30 \\
\end{array}$ & $\begin{array}{l}36,63 \\
37,63 \\
\end{array}$ & $\begin{array}{l}5,37 \\
5,26 \\
\end{array}$ & 37,30 & 29 & ,000 \\
\hline Variaties & & $\mathrm{N}$ & $\bar{X}$ & Ss & $\mathrm{t}$ & $\mathrm{sd}$ & $\mathrm{p}$ \\
\hline Trust & $\begin{array}{l}\text { Pretest } \\
\text { Posttest }\end{array}$ & $\begin{array}{l}30 \\
30\end{array}$ & $\begin{array}{l}38,63 \\
41,50\end{array}$ & $\begin{array}{l}5,28 \\
3,52\end{array}$ & 40,1 & 29 &, 000 \\
\hline
\end{tabular}

Table 1. Examined sig <seems to be 12:05. T test was used for independent samples. Between pretest and posttest scores in both there is a significant differentiation.

Table 2. Class Education Department Student Data

\begin{tabular}{|c|c|c|c|c|c|c|c|}
\hline Variaties & & $\mathrm{N}$ & $\bar{X}$ & Ss & $\mathrm{t}$ & $\mathrm{sd}$ & $\mathrm{p}$ \\
\hline Attention & $\begin{array}{l}\text { Pretest } \\
\text { Posttest } \\
\end{array}$ & $\begin{array}{l}28 \\
28 \\
\end{array}$ & $\begin{array}{l}36,39 \\
37,32 \\
\end{array}$ & $\begin{array}{l}5,20 \\
6,86 \\
\end{array}$ & 36,96 & 27 & , 000 \\
\hline Variaties & & $\mathrm{N}$ & $\bar{X}$ & Ss & $\mathrm{t}$ & sd & $\mathrm{p}$ \\
\hline Trust & $\begin{array}{l}\text { Pretest } \\
\text { Posttest }\end{array}$ & $\begin{array}{l}28 \\
28\end{array}$ & $\begin{array}{l}34,42 \\
37,86\end{array}$ & $\begin{array}{l}6,07 \\
5,66\end{array}$ & 34,42 & 27 & ,000 \\
\hline
\end{tabular}

Table 2. Examined sig <seems to be 12:05. T test was used for independent samples. Between pretest and posttest scores in both there is a significant differentiation.

Table 3. Department of Theology Student Data

\begin{tabular}{|c|c|c|c|c|c|c|c|}
\hline Variaties & & $\mathrm{N}$ & $\bar{X}$ & Ss & $\mathrm{t}$ & sd & $\mathrm{p}$ \\
\hline Attention & $\begin{array}{l}\text { Pretest } \\
\text { Posttest }\end{array}$ & $\begin{array}{l}24 \\
24\end{array}$ & $\begin{array}{l}30,70 \\
37,12\end{array}$ & $\begin{array}{l}8,04 \\
7,47\end{array}$ & 18,69 & 23 & ,000 \\
\hline Variaties & & $\mathrm{N}$ & $\bar{X}$ & Ss & $\mathrm{t}$ & sd & $\mathrm{p}$ \\
\hline
\end{tabular}




\begin{tabular}{llllllll}
\hline \multirow{2}{*}{ Trust } & Pretest & 24 & 38,87 & 6,04 & \multirow{2}{*}{31,50} & 23 & \multirow{2}{*}{000} \\
& Posttest & 24 & 41,29 & 6,79 & & \\
\hline
\end{tabular}

Table 3. Examined sig <seems to be 12:05. T test was used for independent samples. Between pretest and posttest scores in both there is a significant differentiation.

$\mathrm{t}$ test was used for Independent samples in the research. The survey data are analyzed in Table 1 sigma value of the Mathematics Department students $\mathrm{p}<0.05$, Table 2 sigma value of the class teaching students about $\mathrm{p}<0.05$ and table 3 . the sigma value of the Theology department students $\mathrm{p}$ <was found to be 12:05. Based on these results, the use of simulation and animation was determined to be effective for the motivation of the mathematics teaching, classroom teaching and theology department students in computer courses

\section{Results and Discussion}

Kildan (2011) asserts that years of experience and some branches (Class Teacher, Preschool Education and Turkish Education ) affect the student-teacher relationship.

(Ozan, 2009) in his research, suggests that the task of making students interested in the lessons belongs to the teachers. A classroom teacher's occasional lack of discipline leads to problems in this regard and they may use different methods of technical teachers to prevent them.

Based on our research, the results of other studies show that animation technique of computer-aided simulation is more effective than traditional teaching with he success of the students. (Bakaç, Kartal \& Akbayir, 2010-91).

In addition, the use of multimedia content has been shown to increase students' motivation in the course. Because of increasing Interest and relevance of the students to the course, using multimedia of teachers in teaching should be improved continuously and motivational skills will improve the success of teachers, by this way, seminars should be organized for it.. (Özan \& Ozdemir, 2010:787).

In their qualitative research on the causes and solutions of problems, Erdogan et al ( 2010), and in another research on information technology research for the solution of course in classroom management problems, ( Özdener \& Özçoban , 2004), concluded that motivation enhancing activities increase students' achievement.

\section{Suggestions:}

Further research should be conducted to examine:

Student and teacher attitudes towards the use of simulation and animation in lessons

Different teaching methods can be analyzed and identified using the techniques of simulation and animation of his contribution to education.

\section{Reference}

Akbaba, S. (2006). Motivation of Education [In Turkish: Eğitimde Motivasyon] . Atatürk University Kazım Karabekir Journal of the Faculty of Education, 13, , 343-361.

Bakaç, M., Kartal, A., \& Akbay, T. (2010). Since and Physical Activity Computer Aided Simulation of the Effect Student Achievement: Electrical Current for Example (In 
Turkish: Fen ve Fizik Etkinliklerinde Bilgisayar Destekli Simülasyon Tekniğinin Öğrenci Başarısına Etkisi: Elektrik Akımı Örneği). IX. National Science and Mathematics Education Congress Summary Booklet, 91.

Büyüköztürk, Ş., Kılıç Çakmak, E., Akgün, Ö. E., Karadeniz, Ş., \& Demirel, F. (2012). Scientific Research Methods (In Turkish: Bilimsel Araştırma Yöntemleri) (12 b.). Ankara: Pegem A.

Cooke, K. N. (2008). A study of an educational blogging environment in the context of the ARCS model of motivation. Unpublished doctoral dissertation, University of Virginia.

Dede, Y., \& Yaman, S. (2008). Scale Motivation Toward Science Learning: Validity and reliability study (In Turkish: Fen öğrenmeye yönelik motivasyon ölçeği: Geçerlik ve güvenirlik çalışması). Necatibey Educational of Faculty Electronic Scince and Mathematich Education of Magazine, 2(1), 19-37.

Elik, V. (2003). Classroom Management [In Turkish: Sinıf Yöntemi]. Ankara: Nobel Yayınevi.

Elliot, \& Miller. (1999). 3D Studio Max 2. İstanbul: Sistem Yayıncılık Mat.San. ve Tic. A.Ş.

Erdoğan, M.; Kurgun, E.; Tan Şişman, G.; Saltan, F.; Gök, A.; Yıldız, İ. (2010). Classroom Management and classroom discipline problems, A study on the causes and solutions: Information technology course instance [In Turkish: Sınıf yönetimi ve sınıf içi disiplin problemleri, nedenleri ve çözüm önerileri üzerine bir araştırma: Bilişim teknolojileri dersi örneği]. / Educational Sciences: Theory \& Practice, 0(2), Spring, 2010 853-891.

Foley, J., Dam, A., Feiner, S., \& Hughes, J. (1990). Computer graphics principles and practice (2nd edt. b.). New York, U.S.A.: Addison-Wesley.

Hotchkiss, R. H. (1994). Teaching with multimedia: example and issues. Journal of Professional Issues in Engineering Education and Practice, 120(3),, 279-289.

Keenan, K. (1996.). Motivation. (E. KOPARAN., Çev.) İstanbul: Remzi Bookstore.

Keller, J. M. (1983). Motivational design of instruction. C. M. Reigeluth (Ed.), Instructionaldesign theories and models: An overview of their current status içinde (ss.383-434). Mahwah, NJ: Lawrence Erlbaum Associates.

Kutu, H., \& Sözbilir, M. (2011). Adaptation of Instructional Materials Motivation Survey to Turkish: A Validity and Reliability Study. Atatürk University Necatibey Educational of Faculty Electronic Scince and Mathematich Education of Magazine (EFMED), 5(1), 292-312.

Küçükahmet, L. (2001). New Approaches in Classroom Management. Ankara: Nobel Publisher.

Linn, M., Chang, H., Chiu, J., Zhang, H., \& McElhaney, K. (2010). Can desirabledifficulties overcome deception clarity in scientific visualizations? In A. Successful remembering and successful forgetting: a Festschrift in honor of Robert A. New York: Taylor\&Francis.

LittleR.A.J., \& RubinD.R. (1987). Statistical Analysis with Missing Data. New York: John Wiley \& Sons.

Lussier, R. N. (1996). Human relations in organizations: a skill-building approach. .

Maslach, C., Schaufeli, W. B., \& Leiter, M. P. (2001). Job Burnout. . Annual Reviews Psychology, 52(1), , 397-422.

Mickleborough, N., \& Wareham, D. G. (1994). Teaching engineering to increase motivation. . Journal of Professional Issues in Engineering Education and Professional Practice, 120(1), 29-35.

Natriello, G. (1984). Problems in the evaluation of students and student from secondary schools. Journal of Research and Development in Education 17, 14 - 24. 
Neumann, D. L., Hood, M., \& Neumann, M. (2012). An evaluation of computer-based interactive simulations in the assessment of statistical concepts. International Journal for Technology in Mathematics Education, 19(1), 17-23.

Özan, M. B. (2009). The Views Of Students About Classroom Management Rules Applied By Teacher [In Turkish: Öğretmenlerin uyguladıkları sınıf yönetimi kuralları hakkında öğrenci görüşleri]. e-Journal of New World Sciences Academy, 4(2), 1306- 1311.

Özan, M., \& Özdemir, Y. (2010). Effects of the use of multimedia content in the Primary Classroom Management (In Turkish: İlköğretimde Multimedya İçeriklerinin Kullanımının Sınıf Yönetimine Etkisi). 9. National Grade Teacher Training Symposium, , 786-789.

Özdamar, K. (2002). Data Analysis and Statistical Package Programs -2 [In Turkish: Paket Programlar ile Istatistiksel Veri Analizi-]. Eskişehir: Kaan Bookstore.

Özdener, N., \& Özçoban, T. (2004, May). A Project Based Learning Model's Effectiveness on Computer Courses and Multiple Intelligence Theory. Educational Science: Theory\&Practice, Vol. 4( Issue 1, ), p 176, 5p.

Reeve, J., Jang, H., Carrell, D., Jeon, S., \& Barch, J. (2004). Enhancing students' engagement by increasing teachers' autonomy support. Motivation and Emotion, 28, 147-169.

Reschly, A., \& Christenson, S. L. (2006). Research leading to a predictive model of dropout and completion among students with mild disabilities and the role of student engagement. . Remedial and Special Education, 27, 276 - 292.

Seidman, S., \& Zager, J. (1991). A study of coping behaviours and teacher burnout. . Work and Stress, 5, , 205-216.

Stern, D., \& Huber, G. (2012). Active Learning for Students and Teachers. Reports from Eight Countries.

Şahin, A. (2004). Relationship Management and Motivation Theories [In Turkish: Yönetim Kuramları ve Motivasyon İlişkisi]. Selçuk University, Journal of the Institute of Social Sciences (Say1:11.).

TDK. (2015, 06 01). On 06012015 Türk Dil Kurumu: http://www.tdk.gov.tr/ From Retrieved

Yüksel, G. (2004). Ç. E. Edit: Şule ÖZDEM1R, Classroom Managment. Motivation for Education [In Turkish: Sınıf Yönetimi.Ögrenme için Motivasyon]. Ankara: Asil Bookstore. 